Themenheft Nr. 40: CoViD-19 und die digitale Hochschulbildung. Irritationen, Einsichten und Programmatiken

Herausgegeben von Markus Deimann, Marios Karapanos und Klaus Rummler

\title{
Students' Digital Media Usage at the University of Tübingen During the CoViD19 Semester 2020 Compared to 2018
}

\author{
Taiga Brahm ${ }^{1}$ (D) und Marina Pumptow ${ }^{1}$ (D) \\ ${ }^{1}$ Eberhard Karls Universität Tübingen
}

\begin{abstract}
The purpose of this study was to compare students' digital media use during the socalled corona semester in summer of 2020 when universities worldwide moved to online teaching and learning, with data from 2018. Two research questions were at the center of our study: To what extent did students' media use during the digital summer semester 2020 differ from media use in 2018? In which ways is media use in 2020 related to individual factors (e.g., emotional states, social integration, self-efficacy)? In 2020, 207 students at the University of Tübingen participated in an online survey on their digital media use. This data was compared with an existing data set from the same university from 2018 ( $N=808$ students). Results show a significant increase in students' media use across all categories, in particular Learning Management System, online exercises, learning videos, and video conferencing. We also found a significant relation of students' usage of online tools for learning with their feeling of social integration, as well as connections between students' digital media self-efficacy and their learning-relevant emotions. The article discusses these results in the light of other studies on students' media uses and provides first practical implications for lecturers.
\end{abstract}

Studentische Mediennutzung an der Universität Tübingen während des CoViD19Semesters $2020 \mathrm{im}$ Vergleich zu 2018

\begin{abstract}
Zusammenfassung
Diese Studie verfolgte das Ziel, die digitale Mediennutzung Studierender während des sogenannten Corona-Semesters im Sommer 2020 mit Daten aus dem Jahr 2018 zu vergleichen. Zwei Forschungsfragen werden im vorliegenden Papier adressiert: Inwieweit unterscheidet sich die Mediennutzung der Studierenden während des digitalen Sommersemesters 2020 von der Mediennutzung im Jahr 2018? In welcher Weise hängt die Mediennutzung im Jahr 2020 mit individuellen Faktoren zusammen (z. B. emotionale Befindlichkeit, soziale Integration, Selbstwirksamkeit)? Im Jahr 2020 nahmen 207 Studierende
\end{abstract}


der Universität Tübingen an einer Online-Befragung zu ihrer digitalen Mediennutzung teil. Diese Daten wurden mit einem bestehenden Datensatz der gleichen Universität aus dem Jahr 2018 ( $N=808$ Studierende) verglichen. Die Ergebnisse zeigen einen signifikanten Anstieg der Mediennutzung der Studierenden in allen Kategorien, insbesondere beim Learning Management System, Online-Übungen, Lernvideos und Videokonferenzen. Es konnte auch ein signifikanter Zusammenhang zwischen der Nutzung von Online-Tools zum Zwecke des Lernens durch die Studierenden und ihrem Gefühl der sozialen Integration festgestellt werden. Weiterhin gab es Zusammenhänge zwischen der Selbstwirksamkeit der Studierenden in Bezug auf digitale Medien und ihren lernrelevanten Emotionen. Der Artikel diskutiert diese Ergebnisse vor dem Hintergrund anderer Studien zur Mediennutzung von Studierenden und liefert erste praktische Implikationen für Dozierende.

\section{Introduction and Research Questions}

In spring 2020, higher education institutions (HEIs) worldwide were challenged to suddenly shift to fully teaching online (with some very limited exceptions). After the lockdown was announced in Germany, HEls moved their teaching online. For instance, at the University of Tübingen, some departments moved ahead and announced the shift to online teaching on March 16, 2020. Both students and lecturers were deeply affected by the sudden changes in teaching and learning.

However, digital transformation has been a "hot topic" for HEls now for quite some time (e.g., Adedoyin and Soykan 2020; Kopp, Gröblinger, and Adams 2019) since information and communication technologies (ICT) are omnipresent in every part of our lives, also in Higher Education. Accordingly, also before the corona pandemic, media use at HEls was widespread. Between 2012 and 2015, for example, the number of students who owned a smartphone, tablet or notebook has increased significantly, so that by 2015 , digital devices were already omnipresent at HEls (Zawacki-Richter, Dolch, and Müskens 2017). In this context, students' usage habits and attitudes also changed (e.g., Al-Husain and Hammo 2015; Grosch and Gidion 2011; Schulmeister 2006; Zawacki-Richter 2015). While the overall presence of digital media increased, students - depending on their age, gender, and field of study - show quite diverse use patterns in their study environment (e.g., Grosch and Gidion 2011; Zawacki-Richter 2015). Since the CoViD19 pandemic made universities worldwide switch to online teaching, the question arises how students' media use changed in the light of the omnipresent online teaching forced by a pandemic. While some studies already addressed both students' and lecturers' reactions to online teaching in Germany (e.g., Breitenbach 2021; Hafer, Kostädt, and Lucke 2020; Göbel et al. 2020; Skulmowski and Rey 2020), and internationally (Chung, Subramaniam, and Dass 2020; Rapanta et al. 2020; Telles-Langdon 2020; Watchorn and Heckendorf 2020), these studies mostly 
take a descriptive or conceptual stance towards the changes. To our knowledge, empirical comparisons of students' media used before and during the pandemic are yet missing. To contribute to this research gap, this study addresses the following first research question:

RQ1: To what extent did students' media use during the digital summer semester 2020 differ from media use in 2018?

Furthermore, the extent of students' media use is linked to the perceived usefulness of digital media, the students' digital media self-efficacy and their social integration at their HEls (Pumptow and Brahm under review). For social media use, this was also confirmed in a recent literature review identifying that, for instance, selfefficacy, and perceived enjoyment were relevant determinants of students' social media use (Al-Qaysi, Mohamad-Nordin, and Al-Emran 2021). Accordingly, the following second research question is raised:

RQ2: In which ways is media use during the pandemic 2020 related to individual factors (e.g., emotional states, social integration, self-efficacy)?

In doing so, we focus firstly on the use of various media applications that are widespread in university studies and secondly, on the use of social networks, which is supposedly very important for students' social exchange. Both questions are highly relevant to further understand students' digital media use during the first pandemic semester in summer 2020. Our study contributes to research on media usage beyond the pandemic because based on current data, this particular semester is contrasted to the data of a previous semester. This way, the relevant changes can be outlined, and the particularities of the "corona semester" are illustrated, both in terms of general media use and the use social networks. Furthermore, initial explanatory factors, i.e., correlations with individual factors, which are relevant for study related media use are identified. These can serve as a starting point for further investigations of the currently still ongoing digitalized university teaching and, for example, for the development of support measures for students.

The study is based on a data set from the middle of the summer semester 2020, which can be compared with a cross-sectional data set from 2018, collected with a very similar survey instrument (Pumptow and Brahm 2020b).

In the following, the state of research on media use at universities is described. We both consider the state of research before the pandemic and more recent studies which were conducted already during the pandemic. Then, the methodological design of the study and its results are presented. The article ends with a discussion of the results against the background of the state of research as well as implications for teaching in HEIs. 


\section{State of Research on the Use of Digital Media at Universities}

Digital media have the potential for the individualization of learning processes, selfdirected learning, cooperation, and exchange (Kerres 2013). However, Ross, Morrison und Lowther $(2010,19)$ state: «Educational technology is not a homogeneous «intervention» but a broad variety of modalities, tools, and strategies for learning. Its effectiveness, therefore, depends on how well it helps teachers and students achieve the desired instructional goals». For example, digital media can support cooperation and exchange between students, for instance through messenger services (e.g., WhatsApp) or video conferencing systems (e.g., Skype, Zoom). In this way, learning groups can be formed independently by students or used by lecturers in a targeted manner, e.g., in the form of computer-supported group exercises (Grosch 2012).

\subsection{Research Before the Pandemic}

Research on digital media in Higher Education addressed both students' media usage and lecturers' media usage (e.g., Aldahdouh, Nokelainen, and Korhonen 2020). Regarding students' digital media use, Zawacki-Richter et al. $(2015 ; 2016 ; 2017)$ assessed students' media usage in subsequent studies: In 2012, only $56 \%$ of the students had a smartphone, $86 \%$ a laptop, and $9 \%$ a tablet (Zawacki-Richter et al. 2015). Similarly, Schäffer (2015) questioned more than 600 students in 2012 concerning their media usage and found that $93 \%$ of the students owned a laptop and $94 \%$ a cell phone, while only $44 \%$ of the students reported owning a smartphone. Then, in $2015,91 \%$ of students owned a smartphone, $92 \%$ reported owning a laptop, and $40 \%$ a tablet (Zawacki-Richter, Dolch, and Müskens 2017). While these studies were all conducted in Germany, Al-Husain and Hammo (2015) provide results for the usage of mobile devices in Saudi-Arabia ( $N=317$ students). Similar to Germany, 96 percent of the students own a laptop, $86 \%$ a smartphone, and $49 \%$ a tablet. These results are also confirmed by the Ecar-Studies . For instance, in the Ecar-Study 2016, $96 \%$ of the students reported owning a smartphone and $93 \%$ a laptop (Brooks 2016).

In addition to the previous studies, the Ecar-Study (2010) also investigated the importance of learning management systems (LMS) and showed that their relevance increased from 2005 (where about $72 \%$ reported using LMS) to 2010 (with $90 \%$ using LMS). The study also highlighted the importance of social media in the international context, with Facebook reportedly being used for study purposes by about a third of the students (Smith and Borreson Caruso 2010). However, the EcarStudy in 2014 showed that students preferred less usage of social media by lecturers (Dahlstrom and Bichsel 2014). This is an interesting development which is confirmed by Gidion and Weyrich (2017) for the German context. They investigated students' (and lecturers') social media usage at the Karlsruhe Institute for Technology, with $40 \%$ of the $N=500$ students reporting to use video repositories like YouTube for 
studying often while they hardly use media developed for study purposes like online-assessment, learning apps, and massive open online courses (ibid.). In contrast, Zawacki-Richter (2015) found that more than $80 \%$ of the students surveyed in their study also use social networks to communicate concerning study-related aspects such as exchanging literature and documents; to get to know other students or to ask questions concerning self-study.

Furthermore, studies also investigated how the usage of certain media was related to students' achievement. For instance, a study by Kirschner and Karpinski (2010) questioned $N=219$ students at a Midwestern US University, and showed that Facebook users have lower GPAs and spend fewer hours per week studying than nonusers. In a sample of 348 undergraduate students at a university in Hong Kong, Lau (2017) distinguishes between social media use for academic and for non-academic purposes as well as social media multitasking. The latter two were significantly negatively related to academic performance (ibid.). The results, of course, were obtained before studying online was the norm due to the pandemic restrictions.

Pumptow and Brahm (in prep.) conducted a multilevel analysis of students' study-related technology use based on a survey on $N=1284$ students of 105 different disciplines in 2018. In addition to discipline-related differences in technology use, they found a relationship between study-related technology use, the perceived usefulness of this technology, students' digital media self-efficacy and the extent of their social integration. With reference to social cognitive theory (Bandura 1986), it is argued that environmental factors such as fellow students and teachers influence individual behavior (e.g., by acting as role models in technology use) and that social integration functions as a measure of the extent to which students are involved in their environment, i.e., are exposed to this influence (Pumptow and Brahm, in prep.). The Ecar-Study 2019 asked for students' learning environment preferences and found that "While the majority of students $(70 \%)$ prefer mostly or completely faceto-face learning environments, specific demographic factors influence these preferences". These factors include students' work demands, their age, and disabilities (Gierdowski 2019).

\subsection{Research on the CoViD19 Semester}

Recent research already investigated how universities in 20 different countries dealt with the challenge to suddenly change to an almost entirely online mode of teaching. In an early analysis, Crawford et al. (2020) looked into how universities worldwide responded to the pandemic. They distinguished three kinds of responses: a) extension of the semester break which was for instance the case for China, Hong Kong, India, and South Africa; b) campus closures (which applied for most countries except for the United States, Brazil, and Singapore) and c) moving to online teaching which 
applied for most developed economies but only for China, Egypt, and Hongkong among the less developed economies in the sample. Similarly, Ali (2020) investigated how different countries dealt with the challenge to move teaching online.

In Germany, Austria, and Switzerland, an online questionnaire was administered at more than six different HEIs ( $N=3534$ students) between June and July 2020 (Dittler and Kreidl 2020). Regarding their technology equipment, about $78 \%$ of the students reported owning a laptop, $35.3 \%$ a tablet and $80.7 \%$ a smartphone. However, the authors state that this might be due to the wording of the question which asked for technical equipment for online learning (ibid.). Maybe more students owned a smartphone but did not use it for study purposes. Overall, students reported that they managed both the LMS and the online meetings (e.g., Zoom) well. However, students reported less engagement in class with $30.2 \%$ of the students reporting rather less and $22.6 \%$ much less engagement, compared to face-to-face teaching. The Studierendenrat [Study Council] of the University of Heidelberg also asked students ( $N=$ 4136) for their technical equipment: Most students used a computer (either desktop or laptop) at home for the university; about one third of the students reported using a smartphone, supporting the interpretation that smartphones are not predominantly used for learning (Feucht et al. 2020). However, in this study, it was found that some students (roughly $10 \%$ ) do not possess camera, speakers, or a microphone. Depending on the subject area, students reported that they perceived the working demands for participating in seminars somewhat to significantly higher (agreement between $37.4 \%$ and $72.9 \%$ ) (ibid.). Regarding their subject-specific exchange with other students, in most subjects, most students reported they had too little communication (33.3 \% - 70.4\% of the students, depending on the subject area) (Feucht et al. 2020).

Other studies in Germany focused on students' (and lecturers') experiences during the pandemic semester. For instance, Becker and colleagues (2020) described their experiences at the University of Bonn. They asked lecturers $(N=46)$ and complemented this with student data $(N=159-162)$, however, they had only asked how the digital semester had been implemented and how the students dealt with the (new) demands of online teaching. In open question formats, some students discussed the limited variability of learning methods, the higher reading demands, and the missing innovativeness of some lectures (ibid.). At the Technical University in Berlin, $N=204$ teacher education students responded to an online questionnaire regarding their experiences with the online semester (Adam-Gutsch et al. 2020). The students also reported that they felt higher demands for their studies, however, at the same time, they reported that due to more extensive preparation and follow-up, the level of the lectures has risen. The students mostly agreed that studying with synchronous and asynchronous teaching opportunities made self-directed learning possible, however, it did not motivate them further for studying (ibid.). 
Internationally, several studies already evaluate the experiences with the CoViD19 semester. For instance, Chung, Subramaniam, and Dass (2020) reported that at a public university in Malaysia, lecturers used different (free) platforms for online teaching since the learning management system had not been made compulsory. Particularly, they gathered data from $N=399$ students regarding their «readiness for online learning». No significant differences between male and female students were found. These students reported that their most preferred online teaching method was pre-recorded lectures while synchronous formats were less popular (ibid.).

In an online study in Bulgaria, 197 students (73.6 \% females) answered an online questionnaire. It was found that students were overall less satisfied with the quality of teaching and reported that individual course demands became easier while groupwork demands were higher (Angelova 2020).

For online medical education, a study with $N=208$ students in Saudi Arabia found that students encountered challenges regarding communication, assessment, technology, time management as well as pandemic-related anxiety and stress (Rajab, Gazal, and Alkattan 2020).

As both the state of research in Germany and internationally shows, most studies investigated students (and/or lecturers') satisfaction with different modes of online teaching as well as their reaction regarding the (new) demands of online learning (and teaching). To our knowledge, there is hardly any research yet comparing the usage of online media for studying during the pandemic semester to before. Furthermore, the studies reviewed above do not link students' media usage with other relevant factors such as students' self-efficacy or their attitudes towards online learning.

\section{Methodological Approach}

Both in 2018 and summer 2020, students at the University of Tübingen (Southern Germany) were surveyed with a standardized questionnaire, covering media use and other individual factors influencing media use (based on Pumptow and Brahm 2020b). In addition to demographic aspects (age, gender, semester), students were asked for their usage of digital media and social networking sites (SNS), their attitudes towards digital media and their self-efficacy. The frequency of students' media use regarding several media applications was surveyed according to the approved instruments by Grosch and Gidion (2012) and Zawacki-Richter (2015). Some of the items were then summarized in order to reflect study-related online tools in contrast to, for example, more general online tools or communication apps that are most likely not exclusively used purely for study purposes (see also Pumptow and Brahm, in preparation): online exercises, cooperative tools (e.g., google docs), learning videos/videocasts and presentation tools. To assess students' emotions and motivation towards studying, we applied the scales used in Brahm and Jenert (2015). Digital 
media self-efficacy (DMSE) was measured with the corresponding scale by Pumptow and Brahm (2020b) and the scale for academic self-efficacy (ASE) was oriented on Jerusalem and Schwarzer (2002). The scale for social integration was based on the CHE-Quest (Leichsenring 2011).

The first survey was conducted in 2018 at four universities (total sample size: $N=3342$ ), one of which was the University of Tübingen (see Pumptow and Brahm 2020b). For the comparison of the data in 2018 and in 2020, only the students at the University of Tübingen in 2018 ( $N=808$ students) were included in this data analysis. A similar questionnaire was then employed in July 2020 (mid-semester) at the same university, with $N=207$ students participating in the online survey. These samples form the basis of the present comparative analyses. The questionnaire had to be changed slightly in 2020. In 2018, we asked about the frequency of virtual courses, while in 2020, we asked instead about the frequency of synchronous and asynchronous courses (since courses were almost exclusively offered virtually). Therefore, a direct comparison for this question between 2018 and 2020 is not possible.

In every instance, the students were presented with statements and were asked to indicate on a scale from $1=$ «not at all» to $7=$ «fully» or «multiple times a day» to what extent these statements apply to them. For the analyses, a test value based on the mean values of the items (at least three items per scale) was constructed. The instruments fulfilled psychometric requirements both for the data gathered in 2018 (e.g., Cronbach's Alpha .75 - .92; Pumptow and Brahm 2020b) as well as for the data in 2020 (Cronbach's Alpha .80 - .95).

The first research question is addressed by comparing mean values (see Table 2 below) and conducting t-tests of differences between means (Welch's two sample t-test with unequal variances). The relationships between students' media use and individual factors are analyzed by correlation analyses.

\section{Sample Description}

Due to the sample acquisition (invitation via e-mail, no randomized sampling), our sample is a non-representative convenience sample. Female students are overrepresented, both in 2018 and even more in 2020: $31 \%$ male, $68 \%$ female, $1 \%$ diverse $(2018, N=808)$ and $19 \%$ male, $78 \%$ female, $3 \%$ diverse/no answer $(2020, N=207)$. The mean age in 2018 was $M=23.42(S D=3.89)$ and in $2020 M=22.75(S D=3.91)$. Both data sets show a similar distribution with regard to the students' degree aspirations. Most are enrolled in a Bachelor's degree program (57 \% in 2018, 58 \% in 2020), $15 \%$ (2018), respectively $19 \%$ (2020), are aiming for a Master's degree and $28 \%$ (2018), respectively $23 \%$ (2020), are enrolled in other degree programs (such as state examination, for example in case of medicine). 


\section{Results}

\subsection{Comparison of Students' Media Use During the Digital Summer Semester 2020 and the Summer Semester 2018}

The distribution of mobile digital devices is shown in figure 1, for both 2018 and 2020. According to the data from 2018, almost all students owned a smartphone (97\%) and a notebook (96\%) (tablets: $36 \%$ ). Compared to the survey from 2020, a further increase in the prevalence of mobile devices can be noted for smartphones (99\%) and especially for tablets (51\%). On the other hand, there is a slight decrease in the percentage of students who own a laptop, which may be related to the spread of tablets and the replacement of notebooks by (multifunctional) tablets.

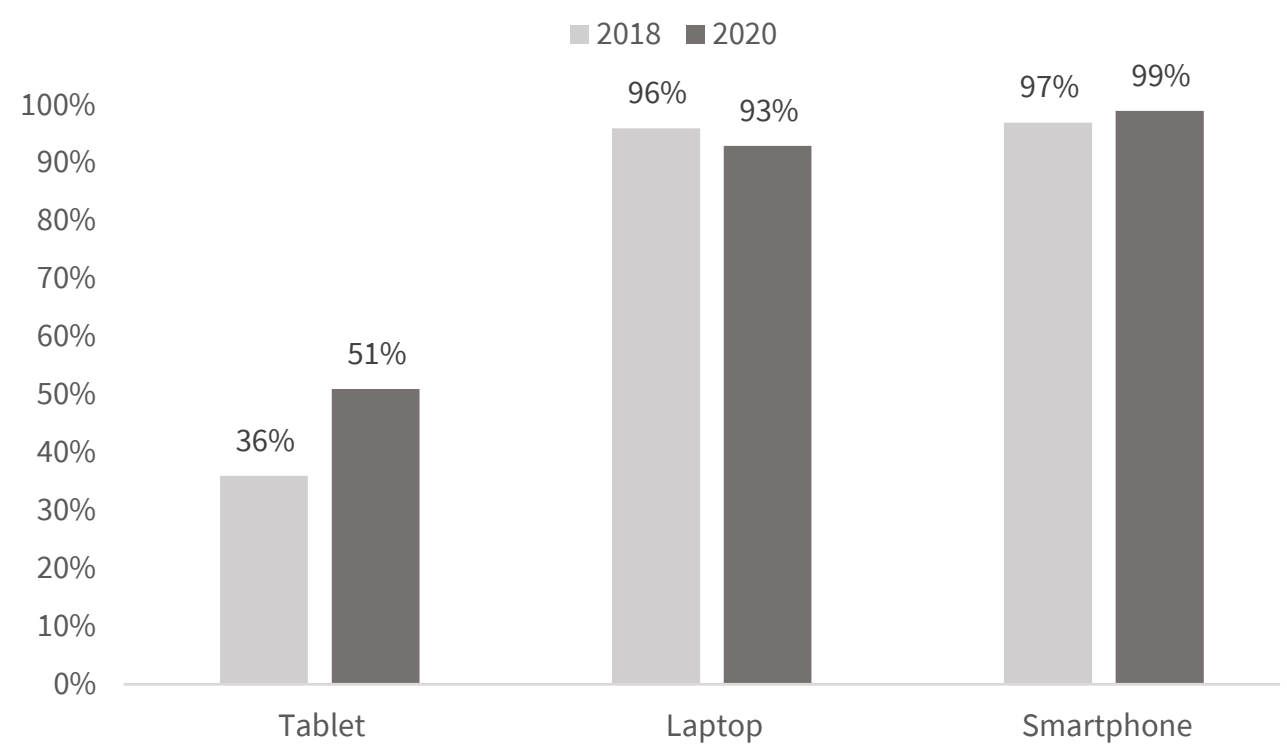

Abb. 1.: Distribution of mobile digital devices among students in 2018 and 2020.

Among all students in 2018 and 2020 who reported using social networking sites (SNSs), we further asked about their use for study purposes (see Table 1) since SNS are not always seen as beneficial for learning. SNSs are used for study-related purposes by $55 \%$ (in 2018) and $38 \%$ (in 2020) of the total student sample. These study matters are very often exam preparation ( $77 \%$ in 2018, $76 \%$ in 2020) and exchange of documents and literature ( $88 \%$ in 2018, $86 \%$ in 2020). While most of the individual areas of use do not differ much between the two years, the proportion of students using SNS for questions related to self-study is considerably higher in 2020 (91\%) than in 2018 (75\%). 


\begin{tabular}{|l|c|c|}
\hline What matters in your studies do you use social networks for? \\
\hline & $\mathbf{2 0 1 8}$ & $\mathbf{2 0 2 0}$ \\
\hline To form study groups & $65 \%$ & $59 \%$ \\
\hline Preparation of term papers, presentations etc. & $65 \%$ & $67 \%$ \\
\hline To establish and maintain contacts (get to know other students etc.) & $67 \%$ & $70 \%$ \\
\hline For questions related to self-study & $75 \%$ & $91 \%$ \\
\hline Exam preparation & $77 \%$ & $76 \%$ \\
\hline Exchange of documents and literature & $88 \%$ & $86 \%$ \\
\hline
\end{tabular}

Tab. 1.: Percentages on the different uses of social networks, measured among all students who indicated to use social networks for their studies (read e.g., for the 2020 sample, $59 \%$ of all study-related SNS users indicated to use these for forming study groups).

In table 2, mean values, standard deviations, sample sizes, results of t-tests and Hedges' $g$ for mean comparison (2018/2020) regarding the frequency of use (indicated on a scale from 1 "not at all used" to 7 "used multiple times a day") for a list of different (digital) media applications are presented. This list includes applications related to university services (e.g., university webpage, study portal, learning management system (LMS)), communication (e.g., social networks, chats, video conferencing), general web tools (e.g., search engines, cloud services) and the above-mentioned study-related tools. Please note again that in 2018, we asked about the frequency of virtual courses, but in 2020, we asked instead about the frequency of synchronous and asynchronous courses (since courses were almost exclusively offered virtually).

In all cases, the average usage frequency increased between 2018 and 2020. Additionally, this difference in mean values is significant $(p<.05)$ for all media applications except for printed textbooks (2018 $M=3.74 ; 2020 M=3.84 ; p=0.44)$. In Table 2 , each mean difference with an effect size $>0.95$ (Hedges' $g$ ) has been marked in bold. This concerns LMS, online exercises, e-exams, university and external e-mail, search engines, cooperative tools, learning videos/videocasts, video conferencing and forum/newsgroups. The biggest difference can be noticed with regard to video conferencing $\left(M_{2018}=1.61 ; M_{2020}=5.34\right)$, also shown in an unusually high effect size (Hedges' $g=2.92$ ). 


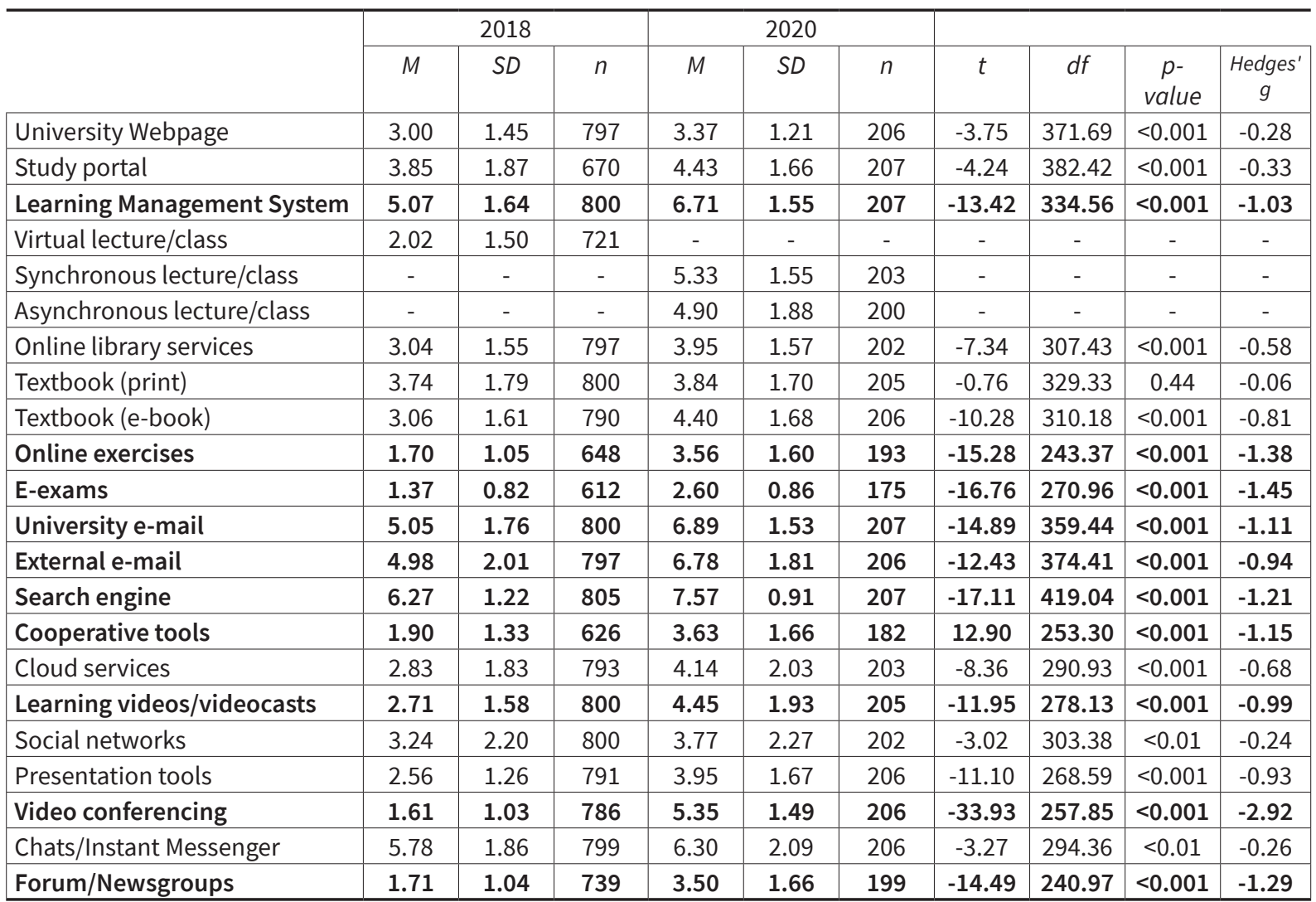

Tab. 2.: Mean, standard deviation, sample size and results of t-tests and Hedges' $g$ for mean comparison regarding the frequency of use of different media applications in 2018 and 2020 (biggest differences in bold).

\subsection{Relationship of Students' Media Use in 2020 with Individual Factors (e.g., Emotional States, Social Integration, Self-Efficacy)}

For the 2020 survey, an additional correlation analysis offers first insights into the (bivariate) relationships between the use of study-related online tools (OTs) and individual factors, i.e., digital media self-efficacy, social integration, and the emotional and motivational factors anxiety (in studying), joy (in studying), performance goal orientation and mastery goal orientation. Table 3 provides the results of the correlation analysis. The frequency of use of study-related online tools is significantly positively, however, rather weakly, correlated with social integration $(r=.21 ; p$ $<0.01$ ). This means that a higher degree of students' social integration goes along with a slightly higher usage frequency of study-related online tools and vice versa. In comparison, study-related online tools and students' self-efficacy regarding digital media (DMSE) are not related, which is rather surprising. Neither is there a notable 
correlation with the remaining emotional and motivational factors $(p>0.05)$. However, DMSE is moderately significantly positively correlated with joy in studying, i.e., the enjoyment that students experience while they study for a certain class $(r=.24 ; p$ $<0.001)$. Furthermore, DMSE is related to students' mastery goal orientation $(r=.19$; $p<0.01)$ and academic self-efficacy $(r=.52 ; p<0.001)$. The higher students' mastery goal orientation or academic self-efficacy, the higher the students' self-efficacy regarding digital media and vice versa. The degree of social integration is moderately significantly positively correlated with joy $(r=.23 ; p<0.001)$ and mastery goal orientation $(r=.22 ; p<0.01)$. However, it appears to be independent of DMSE and performance goal orientation $(p>0.05)$. Anxiety in studying (e.g., regarding the academic demands or assessment) is significantly negatively correlated with mastery goal orientation $(r=-.27 ; p<0.001)$ and academic self-efficacy $(r=-.52 ; p<0.001)$. On the other hand, higher joy in studying goes along with both higher mastery goal orientation $(r=.87 ; p<0.001)$ and academic self-efficacy $(r=.45 ; p<0.001)$ as well as, though much weaker correlated, with higher performance goal orientation $(r=.18 ; p<0.01)$.

\begin{tabular}{|l|l|l|l|l|l|l|l|}
\hline & $\begin{array}{l}\text { study- } \\
\text { related } \\
\text { OTs }\end{array}$ & DMSE & $\begin{array}{l}\text { social } \\
\text { integra- } \\
\text { tion }\end{array}$ & anxiety & $\begin{array}{l}\text { joy in } \\
\text { studying }\end{array}$ & $\begin{array}{l}\text { perfor- } \\
\text { mance } \\
\text { goal } \\
\text { orienta- } \\
\text { tion }\end{array}$ & $\begin{array}{l}\text { mastery } \\
\text { goal } \\
\text { orienta- } \\
\text { tion }\end{array}$ \\
\hline study-related OT & & & & & & & \\
\hline DMSE & 0.00 & & & & & & \\
\hline social integration & $0.21^{\star \star}$ & 0.09 & & & & & \\
\hline anxiety & 0.12 & -0.16 & -0.06 & & & & \\
\hline joy in studying & -0.04 & $0.24^{\star \star \star}$ & $0.23^{\star \star \star}$ & $-0.3^{\star \star \star}$ & & & \\
\hline performance goal orientation & -0.01 & 0.08 & 0.08 & -0.07 & $0.18^{\star \star}$ & & \\
\hline mastery goal orientation & -0.04 & $0.19^{\star \star}$ & $0.22^{\star \star}$ & $-0.27^{\star \star \star}$ & $0.87^{\star \star \star}$ & $0.14^{\star}$ & \\
\hline ASE & -0.07 & $0.52^{\star \star \star}$ & 0.07 & $-0.52^{\star \star \star}$ & $0.45^{\star \star \star}$ & $0.15^{\star}$ & $0.43^{\star \star \star}$ \\
\hline Signif. codes: & & & & & \\
\hline
\end{tabular}

Signif. codes: ${ }^{\star \star \star} p<0.001 ;{ }^{\star \star} p<0.01 ;{ }^{\star} p<0.05$

Tab. 3.: Pearson's correlation of the use of study-related online tools (OTs), digital media selfefficacy (DMSE), social integration, anxiety (in studying), joy (in studying), performance goal orientation and mastery goal orientation and academic self-efficacy (ASE) (significance is indicated by asterisks, $\mathrm{n}=207$ ).

\section{Discussion and Conclusion}

The major aim of this study was to compare students' digital media use during the online semester of summer of 2020 with data that was already available from 2018 (Pumptow and Brahm 2020a). Overall, students were fully equipped with either a laptop, a tablet or a smartphone which was also confirmed in other recent «CoViD19 studies» (e.g., Feucht et al. 2020). In comparison to other studies, our results complement the picture by highlighting the purposes for which students used SNSs, i.e., 
for the preparation of term papers, for keeping in touch with fellow students, for exchanging documents and material as well as for exam preparation. While the purpose "to form study groups" was less often mentioned in the summer term 2020 (in comparison to 2018), students reported that they had used online tools now more to ask questions about self-study ( $91 \%$ compared to $75 \%$ of the students). Reasons for this could be the missing personal exchange with other students which then was shifted to online tools (see also Feucht et al. 2020) but possibly also the limited opportunity to ask lecturers, e.g., during seminars. Additionally, SNSs are used less often for study-related purposes in the 2020 sample compared to the 2018 sample. This decline could be due to a decrease in the overall use of Facebook (Steffens, Schmitt, and Aßmann 2017). Alternatives such as Instagram, which is widely used, may be less suitable for study-related purposes, such as organizing groups or sharing materials. Instead, WhatsApp groups are often used, but these messenger services were covered in a separate question and are not classified here as SNSs.

Extending other studies that predominantly asked for students' satisfaction or the perceived demands of studying fully online (Adam-Gutsch et al. 2020; Kreidl and Dittler 2020; Angelova 2020), our study provides insights into the tools that students used predominantly for study purposes. Little surprisingly, there are significant differences regarding the extent of usage for all learning tools from 2018 to 2020. Comparably bigger differences were found for the frequency of using the university's LMS, the University as well as external e-mail, search engines, online exercises, e-exams, cooperative tools, learning videos/videocasts, video conferencing and forums/newsgroups. Most of these can be explained by the shift of all teaching to online classes and the sudden necessity to use these tools, both for lecturers and students. For instance, learning videos/videocasts were very often used for asynchronous teaching formats. The same goes for online exercises. Video conferencing tools were necessary to participate in synchronous learning formats. The LMS, most likely the included forums/newsgroups as well as (university) email were the tools which were used to organize the seminars and to communicate with students.

Our study also contributes to research on online teaching and learning by investigating the interrelations with students' attitudes towards technology, their social integration, their digital media self-efficacy and other study-related emotions. It is noteworthy that students' extent of using online tools for learning is significantly related to their degree of social integration. This is a promising insight which should be further investigated and provides first practical implications. Environmental factors, such as fellow students and teachers, may influence individual behavior and social integration serves as a measure of the extent to which students are involved in their environment, i.e., exposed to this (peer) influence. It is advisable to support students in their social integration, also and especially during the phases of online teaching, for instance by providing possibilities for (online) collaborative learning. 
While study-related online tools were not related to any other variables assessed in our study, the relation of digital media self-efficacy with students' various emotions is interesting. DMSE is related to students' joy while learning as well as their mastery goal orientation. Both variables are connected to a large extent with students' academic self-efficacy and - as other studies show - also students' performance (e.g., Clark et al. 2014; Hayat, Salehi and Kojuri 2018).

Despite many valuable insights, this study is limited in several ways. First, the data is not representative for the students at the University of Tübingen, neither in the study of 2018, nor in the current study on the online semester. Since the study was conducted online, there might be a slight tendency that students who answered the questionnaire are more positive towards online tools than other students. A second limitation is certainly the cross-sectional nature of our database at each timepoint (2018/2020). Consequently, all assumed causality can only be argued theoretically. Therefore, the correlations found in the data should be tested with the help of longitudinal data sets. In this regard, it is also relevant to note that we cannot outrule the interpretation that the differences between 2018 and 2020 may not be due to the Corona semester but instead result from general developments. Furthermore, the two samples are of different sizes and differ in terms of the distribution of characteristics such as gender. Therefore, their comparability is considerably limited, and it cannot be entirely guaranteed that the differences found would have been the same for more similar samples. Third, we only use self-reported data. However, since Kuncel, Credé, and Thomas (2005) even showed that the reliability of self-reported grades is related to students' actual school performance, it can be assumed that self-reported data are appropriate measures for students' digital media usage as well. Nevertheless, it could be helpful to complement the data, for example, with competence measurements. Fourth, for some items, such as the use of synchronous and asynchronous learning formats, a direct comparison between 2018 and 2020 was not possible. This also emphasizes the special conditions in higher education teaching that students and faculty encountered during the pandemic. In consequence, it should be further investigated to what extent the changes that we discovered in our study will sustain when HEls are able to move back to teaching more in presence again. From a pedagogical point of view, it is, of course, not advisable to stay fully online, since social interaction is an integral part of teaching. However, some of the tools that were now introduced can support student learning, also in the case of «normal» studying.

Nevertheless, this study provides some valuable practical implications for lecturers designing online or hybrid learning environments. First of all, the ubiquity of online learning tools can be seen as an indicator for the necessity to further use digital media to support students' teaching even when the pandemic situation has declined again. Besides the positive relation of the frequency of using online tools for learning purposes and social integration, the connection between students' digital-media 
self-efficacy and students' enjoyment, their mastery goal orientation, and their academic self-efficacy is noteworthy. Although the correlational nature of our study does not allow causal interpretations, lecturers can still be advised to take the prerequisites of technology use into account when integrating digital media in their courses. From our point of view, it is worthwhile to have students' get accustomed with how to use digital media for learning purposes as feeling comfortable with digital media (i.e., having high DMSE) might imply more positive emotions and higher self-efficacy when studying.

Overall, our results confirm that the pandemic-induced necessity to teach online resulted in a boost for online teaching and learning. Also, other HEls reported that after being shocked, a feeling of «anything goes» has evolved (Breinbauer and Schiessl-Foggensteiner 2020). It will be interesting to further investigate to what extent this sudden increase in digital media use will sustain.

\section{References}

Adam-Gutsch, Dörte, Felix Paschel, Diemut Ophardt, and Jana Huck. 2020. «Studieren im Corona-Online-Semester: Bericht zur Befragung der Lehramtsstudierenden der Technischen Universität Berlin im Sommersemester 2020». [Studying in the Corona Online Semester: Report on the Survey of Student Teachers at the Technical University of Berlin in the Summer Semester 2020]. https://doi.org/10.14279/depositonce-11343.

Adedoyin, Olasile Babatunde, and Emrah Soykan. 2020. "Covid-19 pandemic and online learning: the challenges and opportunities». Interactive Learning Environments. https://doi.or g/10.1080/10494820.2020.1813180.

Aldahdouh, Tahani Z., Petri Nokelainen, and Vesa Korhonen. 2020. «Technology and Social Media Usage in Higher Education: The Influence of Individual Innovativeness». SAGE Open 10 (1). https://doi.org/10.1177/2158244019899441.

Al-Husain, Dalal, and Bassam H. Hammo. 2015. «Investigating the readiness of college students for ICT and mobile learning: A case study from King Saud University». International Arab Journal of e-Technology 4 (1): 48-55. http://www.iajet.org/documents/vol.4/no.1/8. pdf.

Ali, Wahab. 2020. "Online and Remote Learning in Higher Education Institutes: A Necessity in Light of COVID-19 Pandemic». Higher Education Studies 10 (3): 16-25. https://doi. org/10.5539/hes.v10n3p16.

Al-Qaysi, Noor, Norhisham Mohamad-Nordin, and Mostafa Al-Emran. 2021. «Factors Affecting the Adoption of Social Media in Higher Education: A Systematic Review of the Technology Acceptance Model». In Recent Advances in Intelligent Systems and Smart Applications, edited by Mostafa Al-Emran, Khaled Shaalan, and Aboul E. Hassanien, 571-84. Berlin: Springer. https://doi.org/10.1007/978-3-030-47411-9_31. 
Angelova, Miglena. 2020. «Students' Attitudes to the Online Umoversity Course of Management in the Context of COVID-19». International Journal of Technology in Education and Science 4 (4): 283-92. https://doi.org/10.46328/ijtes.v4i4.111.

Bandura, Albert. 1986. Social Foundations of Thought and Action: A Social Cognitive Theory. Englewood Cliffs, NY: Prentice Hall.

Becker, Manuel, Felix Leßke, Enrico Liedtke, Eva Hausteiner, Christiane Heidbrink, Jakob Horneber, Tim Huyeng, Shushanik Minasyan, Hendrik W. Ohnesorge, Maximilian Raths, and Penelope Wessel. 2020. «Rückblick auf das erste „Corona-Semester“: Ergebnisse einer semesterbegleitenden Untersuchung der Task Force Digitale Lehre des Instituts für Politische Wissenschaft und Soziologie der Universität Bonn». [Review of the first "Corona Semester": Results of a semester-long study by the Task Force Digital Teaching of the Institute for Political Science and Sociology at the University of Bonn]. Zeitschrift für Politikwissenschaft 30: 681-96. https://doi.org/10.1007/s41358-020-00243-2.

Brahm, Taiga, and Tobias Jenert 2015. "On the assessment of attitudes towards studying Development and validation of a questionnaire." Learning and Individual Differences 43: 233-242. https://doi.org/10.1016/j.lindif.2015.08.019.

Breinbauer, Andreas, and Eva Schiessl-Foggensteiner. 2020. «Vom Krisenmodus zum agil-stabilen Management. Wie Corona die Lehre an Hochschulen verändert hat und verändern wird». [From crisis mode to agile-stable management. How Corona has changed and will change teaching at universities]. In Wie Corona die Hochschullehre verändert, [How Corona is changing higher education teaching] edited by Ullrich Dittler, and Christian Kreidl, 375-91. Wiesbaden: Springer Gabler. https://doi.org/10.1007/978-3-658-32609-8_23.

Breitenbach, Andrea. 2021. «Digitale Lehre in Zeiten von Covid-19: Risiken und Chancen». [Digital teaching in times of Covid-19: risks and opportunities]. https://doi.org/10.25656/01:21274.

Brooks, D. Christopher. 2016. «ECAR Study of Undergraduate Students and Information Technology, 2016». Educause. http://media.clemson.edu/ccit/assessment/ERS1605_ECAR_ STUDENT_SUMMARY_2016.pdf.

Chung, Ellen, Geetha. Subramaniam, and Laura Christ Dass. 2020. «Online Learning Readiness Among University Students in Malaysia Amidst Covid-19». Asian Journal of University Education 16 (2): 46-58. https://doi.org/10.24191/ajue.v16i2.10294.

Clark, M. H., Steven C. Middleton, Daniel Nguyen, and Lauren K. Zwick. 2014. «Mediating relationships between academic motivation, academic integration and academic performance». Learning and Individual Differences 33: 30-38. https://doi.org/10.1016/j.lindif.2014.04.007.

Crawford, Joseph, Kerryn Butler-Henderson, Rudolph. Jürgen, Bashar Malkawi, Matt Glowatz, Rob Burton, Paola Magni, and Sophia Lam. 2020. «COVID-19: 20 Countries' Higher Education Intra-Period Digital Pedagogy Responses». Journal of Applied Learning \& Teaching 3 (1): 1-20. https://doi.org/10.37074/jalt.2020.3.1.7.

Dahlstrom, Eden, and Jaqueline Bichsel. 2014. «ECAR Study of Undergraduate Students and Information Technology, 2014». http://www.educause.edu/ecar. 
Dittler, Ullrich, and Christian Kreidl, Eds. 2020. Wie Corona die Hochschullehre verändert: Erfahrungen und Gedanken aus der Krise zum zukünftigen Einsatz von eLearning. [How Corona is changing higher education teaching: Experiences and thoughts from the crisis on the future use of eLearning]. Wiesbaden: Springer Gabler. https://doi.org/10.1007/978-3-65832609-8.

Feucht, Tabea, Kirsten-Heike Pistel, Cedric Reif, and Henrike Arnold. 2020. «Die komplexen Auswirkungen des "Corona-Semesters" auf die Lehre: Die Ergebnisse der Umfrage des Studierendenrates der Universität Heidelberg». [The Complex Effects of the "Corona Semester" on Teaching: The Results of the Survey by the Student Council of Heidelberg University]. HINT - Heidelberg Inspirations for Innovative Teaching 1 (1): 105-19. https://doi. org/10.11588/hint.2020.1.77694.

Gidion, Gerd, and Michael Weyrich, Eds. 2017. Mediale Hochschul-Perspektiven 2020 in Baden-Württemberg: empirische Untersuchung im Rahmen der Allianz "Forward IT". [Media University Perspectives 2020 in Baden-Württemberg: Empirical Investigation within the "Forward IT" Alliance]. Karlsruhe: KIT Scientific Publishing. https://doi.org/10.5445/ KSP/1000064688.

Gierdowski, Dana C. 2019. «ECAR Study of Undergraduate Students and Information Technology, 2019». Research report. https://library.educause.edu/resources/2019/10/2019-studyof-undergraduate-students-and-information-technology.

Göbel, Kerstin., Elena Makarova, Katharina Neuber, and Tomas Kaqinari. 2020. «Der Übergang zur digitalen Lehre an den Universitäten Duisburg-Essen und Basel in Zeiten der CoronaPandemie». [The Transition to Digital Teaching at the Universities of Duisburg-Essen and Basel in Times of the Corona Pandemic]. In Wie Corona die Hochschullehre verändert, [How Corona is changing higher education teaching], edited by Ullrich Dittler, and Christian Kreidl, 351-74. Wiesbaden: Springer Gabler. https://doi.org/10.1007/978-3-658-326098_22.

Grosch, Michael. 2012. Mediennutzung im Studium: Eine empirische Untersuchung am Karlsruher Institut für Technologie [Media use in studies. An empirical study at the Karlsruhe Institute of Technology]. Aachen: Shaker. Zugl. Karlsruhe, Karlsruher Inst. für Technologie, Diss., 2011 u.d.T. Grosch, Michael: Phänomene und Strukturen der Mediennutzung im Studium.

Grosch, Michael, and Gerd Gidion. 2011. Mediennutzungsgewohnheiten im Wandel: Ergebnisse einer Befragung zur studiumsbezogenen Mediennutzung [Changing media use habits: results of a survey on study-related media use]. Karlsruhe: KIT Scientific Publishing.

Hafer, Jörg, Peter Kostädt, and Ulrike Lucke. 2020. «Das Corona-Virus als Treiber der Digitalisierung? Eine kritische Analyse am Beispiel der Universität Potsdam». [The Corona Virus as a Driver of Digitization? A Critical Analysis Using the Example of the University of Potsdam] In Wie Corona die Hochschullehre verändert, [How Corona is changing higher education teaching] edited by Ullrich Dittler, and Christian Kreidl, 219-42. Wiesbaden: Springer Gabler. https://doi.org/10.1007/978-3-658-32609-8_15. 
Hayat, Ali Asghar, Asieh Salehi, and Javad Kojuri. 2018. «Medical Student's Academic Performance: The Role of Academic Emotions and Motivation». Journal of Advances in Medical Education \& Professionalism 6 (4): 168-75. https://www.ncbi.nlm.nih.gov/pmc/articles/ PMC6191829/

Jerusalem, Matthias, and Ralf Schwarzer. 2002. «Das Konzept der Selbstwirksamkeit: [The concept of self-efficacy]. In Selbstwirksamkeit und Motivationsprozesse in Bildungsinstitutionen, [Self-efficacy and motivation processes in educational institutions], edited by Matthias Jerusalem, and Diether. Hopf, 28-53. Zeitschrift für Pädagogik. Beiheft 33. Weinheim: Beltz. https://doi.org/10.25656/01:3930.

Kerres, Michael. 2013. Mediendidaktik. Konzeption und Entwicklung mediengestuetzter Lernangebote [Media didactics. Conception and development of media-supported learning offers]. Muenchen: Oldenbourg.

Kirschner, Paul A., and Aryn C. Karpinski. 2010. «Facebook ${ }^{\circledR}$ and academic performance». Computers in Human Behavior 26 (6): 1237-45. https://doi.org/10.1016/j.chb.2010.03.024.

Kopp, Michael, Ortrun Gröblinger, and Simone Adams. 2019. «Five Common Assumptions That Prevent Digital Transformation at Higher Education Institutions». In INTED2019: Conference Proceedings, edited by L. Gómez Chova, A. López Martínez, and I. Candel Torres, 1448-57. https://doi.org/10.21125/inted.2019.0445.

Kreidl, Christian, and Ullrich Dittler. 2020. «Die Corona-Lehre: Wahrnehmung der Studierenden». [The Corona teaching: student perception]. In Wie Corona die Hochschullehre verändert, [How Corona is changing higher education teaching], edited by Ullrich Dittler, and Christian Kreidl, 15-35. Wiesbaden: Springer Gabler. https://doi.org/10.1007/978-3-65832609-8_2.

Kuncel, Nathan R., Marcus Credé, and Lisa L. Thomas. 2005. «The Validity of Self-Reported Grade Point Averages, Class Ranks, and Test Scores: A Meta-Analysis and Review of the Literature». Review of Educational Research 75 (1): 63-82. https://doi.org/10.3102/00346543075001063.

Leichsenring, Hannah. 2011. "CHE-Quest-Ein Fragebogen zum Adaptionsprozess zwischen Studierenden und Hochschule-Entwicklung und Test des Fragebogens». [CHE-Quest - A questionnaire on the process of adoption between students and higher education institutions - Development and testing of the questionnaire]. https://www.che.de/download/ che_ap144_quest_entwicklung_und_test_des_fragebogens-pdf/?ind=5d1a0805870f2\&fil ename=CHE_AP144_QUEST_Entwicklung_und_Test_des_Fragebogens.pdf.

Pumptow, Marina, and Taiga Brahm. In preparation. «The Relevance of Digital Media Self-Efficacy and Media Usage for Achievement in Higher Education».

Pumptow, Marina, and Taiga Brahm. 2020a. «Erkenntnisse zur medialen Selbstwirksamkeit von Studierenden». [Findings on students' media-related self-efficacy]. In Studierende - Medien - Universität: Einblicke in studentische Medienwelten [Students - Media - University. Insights into student media worlds], edited by Sandra Hofhues, Mandy Schiefner-Rohs, Sandra Aßmann, and Taiga Brahm, 107-29. Münster: Waxman. https://doi. org/10.31244/9783830990499. 
Pumptow, Marina, and Taiga Brahm. 2020b. «Students' Digital Media Self-Efficacy and Its Importance for Higher Education Institutions: Development and Validation of a Survey Instrument». Technology, Knowledge and Learning. https://doi.org/10.1007/s10758-020-09463-5.

Rajab, Mohammad H., Abdalla M. Gazal, and Khaled Alkattan. 2020. "Challenges to Online Medical Education During the COVID-19 Pandemic». Cureus 12 (7): e8966. https://doi. org/10.7759/cureus.8966.

Rapanta, Chrysi, Luca Botturi, Peter Goodyear, Lourdes Guàrdia, and Marguerite Koole. 2020. "Online University Teaching During and After the Covid-19 Crisis: Refocusing Teacher Presence and Learning Activity». Postdigital Science and Education 2: 923-45. https://doi. org/10.1007/s42438-020-00155-y.

Ross, Steven. M., Gary R. Morrison, and Deborah. L. Lowther. 2010. «Educational technology research past and present: Balancing rigor and relevance to impact school learning». Contemporary Educational Technology 1 (1): 17-35. https://doi.org/10.30935/cedtech/595.

Schäffer, Dennis. 2015. «E-Learning als Teil des persönlichen, intentionalen Lernraumes im Studium. Eine explorative Studie an Studierenden an der Fakultät für Erziehungswissenschaft an der Universität Bielefeld». [E-learning as part of the personal, intentional learning space in studies. An explorative study of students at the Faculty of Education at Bielefeld University]. https://doi.org/10.25656/01:10912.

Schulmeister, Rolf. 2006. eLearning Einsichten und Aussichten [eLearning insights and prospects]. München: Oldenbourg.

Skulmowski, Alexander, and Günter Daniel Rey. 2020. «COVID-19 as an Accelerator for Digitalization at a German University: Establishing Hybrid Campuses in Times of Crisis». Human Behavior and Emerging Technologies 2 (3): 212-16. https://doi.org/10.1002/hbe2.201.

Smith, Shannon D., and Judith Borreson Caruso. 2010. «The ECAR Study of Undergraduate Students and Information Technology: 2010 Key Findings». Educause. https://library.educause.edu/-/media/files/library/2010/10/ekf1006-pdf.pdf.

Steffens, Yannic, Inga Lotta Schmitt, and Sandra Aßmann. 2017. «Mediennutzung Studierender: über den Umgang mit Medien in hochschulischen Kontexten-Systematisches Review nationaler und internationaler Studien zur Mediennutzung Studierender». [Students' media use: on the use of media in higher education contexts Systematic review of national and international studies on students' media use]. https://your-study.info/wp-content/ uploads/2018/01/Review_Steffens_Schmitt_Assmann.pdf.

Telles-Langdon, David M. 2020. «Transitioning University Courses Online in Response to COVID-19». Journal of Teaching and Learning 14 (1): 108-19. https://doi.org/10.22329/jtl. v14i1.6262.

Watchorn, Deirdre, and Esther Heckendorf. 2020. «We asked 3000+ Academics How They're Coping with Covid-19: This is What We found». https://blog.degruyter.com/we-asked3000-academics-how-theyre-coping-with-covid-19-this-is-what-we-found/.

Zawacki-Richter, O., C. Dolch, and W. Müskens. 2017. «Weniger ist mehr? Studentische Mediennutzung im Wandel». [Less is more? Changing student media use]. Synergie Fachmagazin für Digitalisierung in der Lehre 3: 70-73. https://uhh.de/vs54g. 
Zawacki-Richter, O., W. Müskens, U. Krause, U. Alturki, and A. Aldraiweesh. 2015. «Student media usage patterns and non-traditional learning in higher education». The International Review of Research in Open and Distributed Learning 16 (2): 136-70. https://doi.org/10.19173/ irrodl.v16i2.1979

Zawacki-Richter, Olaf. 2015. «Zur Mediennutzung im Studium - unter besonderer Berücksichtigung heterogener Studierender». [On media use in studies - with special consideration of heterogeneous students]. Zeitschrift für Erziehungswissenschaft 18 (3): 527-49. https://doi. org/10.1007/s11618-015-0618-6.

Zawacki-Richter, Olaf, Carina Kramer, and Wolfgang Müskens. 2016. «Studiumsbezogene Mediennutzung im Wandel - Querschnittdaten 2012 und 2015 im Vergleich». [Changing studyrelated media use - comparison of cross-sectional data for 2012 and 2015]. Schriftenreihe zum Bildungs- und Wissenschaftsmanagement 1. https://openjournal.uni-oldenburg.de/ index.php/bildungsmanagement/article/view/101/. 